\title{
Tomasz Tyburcy
}

\section{Kradzież dobra o szczególnym znaczeniu dla kultury (art. 294 § k.k.)}

Kradzież dobra o szczególnym znaczeniu dla kultury stanowi typ kwalifikowany kradzieży (art. 294 § 2 k.k.). Przedmiot wykonawczy tego przestępstwa został określony zwrotem niedookreślonym, który nie posiada definicji legalnej. Szczególne znaczenie dobra dla kultury wiąże się $\mathrm{z}$ jego unikatowym i niepowtarzalnym charakterem lub znaczną wartością. Zabór w celu przywłaszczenia cudzej rzeczy ruchomej stanowiącej dobro o szczególnym znaczeniu dla kultury polega na wykraczającym poza ramy zwykłego, użycia umyślnym bezprawnym wykonywaniu przez sprawcę praw właściciela w stosunku do rzeczy, na rozporządzeniu nią jak swą własnością.

\section{Wstęp}

Kradzież dobra o szczególnym znaczeniu dla kultury jest typem kwalifikowanym kradzieży. Zgodnie z art. 294 § 1 k.k. ${ }^{1}$, kto dopuszcza się przestępstwa określonego w art. $278 \S 1$ lub 2, art. $284 \S 1$ lub 2, art. $285 \S 1$, art. $286 \S 1$, art. $287 \S 1$, art. $288 \S 1$ lub 3, lub w art. $291 \S 1$ k.k., w stosunku do mienia znacznej wartości, podlega karze pozbawienia wolności od roku do lat 10. Zgodnie $\S 2$ tego przepisu, tej samej karze podlega sprawca, który dopuszcza się przestępstwa wymienionego $\mathrm{w} \S 1 \mathrm{w}$ stosunku do dobra o szczególnym znaczeniu dla kultury.

Sprawca kradzieży zabiera cudzą rzecz ruchomą w celu przywłaszczenia. J. Wojciechowski trafnie podkreśla, że: „wszystkie czysto przedmiotowe elementy przestępstwa kradzieży podporządkowane są temu kierunkowemu nastawieniu sprawcy, który przez swoje działanie dąży do uzyskania wszystkich atrybutów właściciela względem cudzego mienia, będącego we władztwie innej osoby. Tak więc chodzi tu nie tylko o aktualizację $\mathrm{w}$ świadomości sprawcy znamion przedmiotowych $\mathrm{w}$ momencie popełnienia czynu, lecz nadto o szczególne znamię strony podmiotowej - «cel» przywłaszczenia, bez którego to zachowanie się sprawcy jest z punktu widzenia prawa karnego obojętne"2.

\footnotetext{
${ }^{1}$ Ustawa z 6.6.1997 r. - Kodeks karny, t.j. Dz.U. z 2016 r. poz. 1137 z późn. zm, dalej jako k.k.

2 J. Wojciechowski, Pojęcie ,celu przywłaszczenia” jako elementu kradzieży, Annales UMCS, Sectio G, vol XVIII (1971), s. 255-256.
} 
H. Welzel wskazuje natomiast, że wola przywłaszczenia powinna być motywem zaboru³ Nadaje ona działaniu sprawcy swoisty sens.

Orzecznictwo zwraca uwagę na to, że sprawca kradzieży w czasie czynu powinien obejmować zamiarem zarówno zabór, jak i przywłaszczenie tego mienia. „Przywłaszczenie cudzej rzeczy ruchomej polega na wykraczającym poza ramy zwykłego, chwilowego jej użycia umyślnym bezprawnym wykonywaniu przez sprawcę praw właściciela w stosunku do rzeczy, na rozporządzeniu nią jak swą własnością. Nie jest przy tym konieczny warunek, by sprawca włączył rzecz na trwałe do swego majątku. Przywłaszczenie następuje przez uzewnętrznienie ze strony sprawcy słowem lub czynem jednoznacznego zamiaru rozporządzania rzeczą jak własną bez dążenia do jej zwrotu właścicielowi w pierwotnym stanie. Uzewnętrznieniem takiego zamiaru może być np. odmowa sprawcy oddania rzeczy właścicielowi, skonsumowanie, zużycie rzeczy co najmniej $\mathrm{w}$ stopniu widocznie zmniejszającym jej wartość, zmiana substancji, przeznaczenia rzeczy, zbycie czy wreszcie jej porzucenie". 4

\section{Treść i zakres znamienia kwalifikującego (dobro o szczególnym znaczeniu dla} kultury)

Pojęcie „dobro kultury” pojawiło się po raz pierwszy w prawie międzynarodowym w Konwencji o ochronie dóbr kulturalnych $\mathrm{w}$ razie konfliktu zbrojnego podpisanej w Hadze 14.5.1954 r. . Zgodnie z tym aktem, za dobra kulturalne uważa się, „bez względu na ich pochodzenie oraz na osobę ich właściciela:

a) dobra ruchome lub nieruchome, które posiadają wielką wagę dla dziedzictwa kulturalnego narodu, na przykład zabytki architektury, sztuki lub historii, zarówno religijne, jak świeckie; stanowiska archeologiczne; zespoły budowlane posiadające jako takie znaczenie historyczne lub artystyczne; dzieła sztuki, rękopisy, książki i inne przedmioty o znaczeniu artystycznym, historycznym lub archeologicznym, jak również zbiory naukowe i poważne zbiory książek, archiwaliów lub reprodukcji wyżej określonych dóbr;

b) gmachy, których zasadniczym i stosowanym w praktyce przeznaczeniem jest przechowywanie lub wystawianie dóbr kulturalnych ruchomych, określonych pod lit. a),

\footnotetext{
${ }^{3}$ H. Welzel, Das deutsche Strafrecht, Berlin 1965, s. 309.

${ }^{4}$ Uchwała SN z 30.12.1965 r., RNw 44/65, Orzecznictwo Sądu Najwyższego Izba Karna i Wojskowa 1966, nr 3 , poz. 29.

${ }_{5}^{5}$ Konwencja o ochronie dóbr kulturalnych w razie konfliktu zbrojnego podpisana w Hadze 14.5.1954 r., Dz.U. z $1957 \mathrm{Nr} 46$, poz. 212, załącznik.
} 
na przykład muzea, wielkie biblioteki, składnice archiwalne, jak również schrony mające na celu przechowywanie $\mathrm{w}$ razie konfliktu zbrojnego, dóbr kulturalnych ruchomych, określonych pod lit. a);”.

Kolejnym aktem prawa międzynarodowego definiującym omawiane pojęcie była Konwencja dotycząca środków zmierzających do zakazu i zapobiegania nielegalnemu przywozowi, wywozowi i przenoszeniu własności dóbr kultury, sporządzona w Paryżu 17.11.1970 r. ${ }^{6}$. Zgodnie z jej art. 1: „za dobra kultury uważane są dobra, które ze względów religijnych lub świeckich uznawane są przez każde Państwo za mające znaczenie dla archeologii, prehistorii, literatury, sztuki lub nauki i które należą do następujących kategorii:

a) rzadkie zbiory i okazy z dziedziny zoologii, botaniki, mineralogii i anatomii; przedmioty przedstawiające wartość paleontologiczną ${ }^{7}$;

b) dobra mające związek $\mathrm{z}$ historią, $\mathrm{w}$ tym również $\mathrm{z}$ historią nauki i techniki, historią wojskowości i historią społeczną, a także dobra pozostające w związku z historią życia przywódców, myślicieli, naukowców i artystów narodowych oraz ważnych dla narodu wydarzeń;

c) przedmioty uzyskane drogą wykopalisk archeologicznych (legalnych i nielegalnych) i odkryć archeologicznych;

d) elementy pochodzące z rozebranych zabytków artystycznych lub historycznych albo ze stanowisk archeologicznych;

e) antyki liczące ponad 100 lat, takie jak napisy, monety i wyryte pieczęcie;

f) materiały etnologiczne;

g) dobra, przedstawiające wartość artystyczną, takie jak:

(I) obrazy, malowidła i rysunki wykonane w całości ręcznie, na jakimkolwiek podkładzie i przy wykorzystaniu dowolnego tworzywa (z wyjątkiem rysunków przemysłowych i artykułów przemysłowych ręcznie zdobionych);

(II) oryginalne dzieła sztuki posągowej i rzeźby wykonane z dowolnego tworzywa;

\footnotetext{
${ }^{6}$ Konwencja dotycząca środków zmierzających do zakazu i zapobieganiu nielegalnemu przywozowi, wywozowi i przenoszeniu własności dóbr kultury, sporządzona w Paryżu 17.11.1970 r. , Dz.U. z 1974 Nr 20, poz. 106 z późn. zm.

${ }^{7}$ Trafnie wskazuje się w literaturze (J. Kaczmarek i M. Kierszka, Pojęcie „,mienie w wielkich rozmiarach”, „,zniszczenie $w$ świecie roślinnym lub zwierzęcym $w$ znacznych rozmiarach” oraz „dobra o szczególnym znaczeniu dla kultury" w kodeksie karnym, Prokuratura i Prawo 2000, nr 3, s. 119), że byłoby niewłaściwe zakwalifikowanie zniszczenia pewnych okazów przyrody stanowiących „dobro o szczególnym znaczeniu dla kultury” (głównie z uwagi na ich walory historyczne) z art. 187 k.k., który przewiduje sankcję niewspółmiernie niższą od tej z art. $294 \S 2$ k.k. Tak też W. Radecki, Ochrona dóbr kultury w nowym kodeksie karnym, Prokuratura i Prawo 1998, nr 2, s. 14.
} 
(III) oryginały sztychów, rycin i litografii;

(IV) oryginały zestawów i montaży artystycznych wykonane z dowolnego tworzywa;

h) rzadkie rękopisy i inkunabuły, dawne książki, dokumenty i publikacje mające szczególne znaczenie (historyczne, artystyczne, naukowe, literackie itp.), w postaci pojedynczych egzemplarzy lub w zbiorach;

i) znaczki pocztowe, skarbowe i podobnego rodzaju w postaci pojedynczych egzemplarzy lub w zbiorach;

j) archiwa, w tym archiwa fonograficzne, fotograficzne i filmowe ${ }^{8}$;

k) liczące ponad sto lat meble oraz dawne instrumenty muzyczne”.

Zdaniem A. Gereckiej-Żołyńskiej, definicja Konwencji paryskiej uzyskała nijako charakter modelowy, gdyż późniejsze akty prawne odwołują się do niej określając termin „dobro kultury” ${ }^{9}$. Podkreśla ona: „Tworząc wykazy dóbr kultury w poszczególnych państwach nie można ustalić całkowicie wspólnych kryteriów i zachować zasadę proporcjonalności. Natomiast niewątpliwie bardziej powinno być zaakcentowane kryterium narodowe. Pojęcie dobra kultury nie zawiera elementu wskazującego na pochodzenie dzieła, dzieło sztuki może uchodzić za dobro kultury w różnych państwach. Wartości artystyczne, literackie, archeologiczne i historyczne nie zawsze wskazują na pochodzenie dzieła. Dla jego określenia może mieć np. znaczenie ujawnienie więzi, jaka istnieje pomiędzy dobrem kultury a państwem, w którym się ono znajduje, można byłoby uwzględnić także i takie elementy, jak sposób nabycia i okres pobytu" ${ }^{10}$. Wykluczyć należy możliwość określenia przynależności z uwagi na miejsce powstania dzieła czy narodowość twórcy ${ }^{11}$.

Artykuł 2 ustawy z 15.2.1962 r. o ochronie dóbr kultury stanowił, że: „,dobrem kultury w rozumieniu ustawy jest każdy przedmiot ruchomy lub nieruchomy, dawny lub współczesny, mający znaczenie dla dziedzictwa i rozwoju kulturalnego ze względu na jego wartość historyczną, naukową lub artystyczną"12. Ustawa ta została uchylona ustawą z 23.7.2003 r. o ochronie zabytków i opiece nad zabytkami, która nie zawiera jednak definicji omawianego terminu ${ }^{13}$. Definiuje natomiast pojęcie zabytku (art. 3 pkt 1).

\footnotetext{
${ }^{8}$ J. Kaczmarek i M. Kierszka (op. cit., s. 119) trafnie dopuszczają możliwość uznania za „dobro o szczególnym znaczeniu dla kultury" materiałów archiwalnych w rozumieniu ustawy z 14.7.1983 r. o narodowym zasobie archiwalnym i archiwach. Ich zdaniem: „pominięcie materiałów archiwalnych w rozumieniu omawianej definicji byłoby o tyle błędnym rozwiązaniem, o ile stanowić mogą one niejednokrotnie przedmioty o szczególnym znaczeniu dla kultury. Tak też W. Radecki, Ochrona..., s. 13-14.

${ }^{9}$ A. Gerecka-Żołyńska, W kwestii definicji dobra kultury i dzieła sztuki, Prokuratura i Prawo 1999, nr 9, s. 107.

${ }^{10}$ Ibidem, s. 97.

11 A. Gerecka-Żołyńska, Restytucja dóbr kultury a wolny rynek sztuki, Ruch Prawniczy Ekonomiczny i Socjologiczny 1996, nr 2, s. 45-46.

${ }^{12}$ Ustawa z 15.2. 1962 r. o ochronie dóbr kultury, Dz.U. Nr 10, poz. 48 z pózn zm.

${ }^{13}$ Ustawa z 23.7.2003 r. o ochronie zabytków i opiece nad zabytkami, Dz.U. Nr 162, poz. 1568 z pózn. zm.
} 
Stanowi go nieruchomość lub rzecz ruchoma, ich część lub zespół, będący dziełem człowieka lub związany z jego działalnością i stanowiący świadectwo minionej epoki bądź zdarzenia, którego zachowanie leży $\mathrm{w}$ interesie społecznym ze względu na posiadaną wartość historyczną, artystyczną lub naukową. Administracyjne grupowanie zabytków, pomników przyrody, zasobów muzealnych i bibliotecznych nie przesądza, że jedynie obiekty wpisane do rejestru zabytków, uznane za pomnik przyrody albo wpisane do inwentarza muzeum narodowego (zasób biblioteczny) mogą stanowić „dobro o szczególnym znaczeniu dla kultury”. Niemniej dobrem o szczególnym znaczeniu dla kultury może być szczególnie rzadki okaz przyrody chroniony przez ustawę z 16.4.2004 r. o ochronie przyrody.

Ustawodawstwo nie zawiera definicji „dobra o szczególnym znaczeniu dla kultury”. Termin ten jako znamię kwalifikujące pojawia się także $\mathrm{W}$ art. 125 § 2 k.k. W doktrynie wskazuje się, że dobro o szczególnym znaczeniu dla kultury stanowi dobro kulturalne o wyjątkowej wartości, szczególnym znaczeniu i niepowtarzalnym charakterze. Nie jest ono tożsame z pojęciem „zabytku” oraz „dobra kulturalnego"14. Wskazuje się, że każdy zabytek stanowi dobro kultury, lecz niekoniecznie musi mieć ono szczególne znaczenie dla kultury. Dobrami kultury mogą być także dobra, która nie są zabytkami ${ }^{15}$.

W. Daszkiewicz podnosił, że przestępstwa przeciwko dobrom kultury powinny zostać zgrupowane $\mathrm{w}$ oddzielnym rozdziale k.k. albo $\mathrm{w}$ ustawie o ochronie dóbr kultury ${ }^{16}$. Proponował, aby istniał typ wieloodmianowy kryminalizujący kradzież, przywłaszczenie, wyłudzenie oraz zniszczenie lub uszkodzenie zabytku. Natomiast przedmiot typu kwalifikowanego określił on jako zabytek o szczególnym znaczeniu historycznym, naukowym albo artystycznym lub stanowiący mienie znacznej wartości ${ }^{17}$.

Przedmiot wykonawczy typu z art. $294 \S 2$ k.k. nie musi mieć wartości majątkowej. Wydaje się jednak, że jego wysoka wartość jest okolicznością obciążającą i powinna wpływać na wymiar kary. Podkreśla się w literaturze, że przedmiotem czynności wykonawczej omawianego typu może być przedmiot niewpisany do rejestru zabytków i nieuznawany za pomnik historii, niewpisany do inwentarza biblioteki lub niewchodzący w skład biblioteki, stanowiący jednak dobro kulturalne, któremu przydawane jest szczególne

\footnotetext{
${ }^{14}$ M. Dąbrowska-Kardas, P. Kardas [w:] A. Zoll, Kodeks karny. Komentarz, Część szczególna, t. III, Kraków 2006, s. 484.

${ }^{15}$ A. Księżopolska-Kukulska, Dobra o kultury jako przedmiot ochrony w prawie karnym, Prokurator 2007, $\mathrm{nr} 2$, s. 114.

${ }^{16}$ W. Daszkiewicz, Kradzież i przywłaszczenie zabytku, RPEiS 1987, nr 3, s. 98. W. Radecki (Przestepstwa przeciwko dobrom kultury i innym dobrom intelektualnym, Przegląd Prawa Karnego 1993, nr 8, s. 33 i n.) podczas prac na projektem k.k. proponował wprowadzenie nowego rozdziału, który grupowałby przestępstwa przeciwko dobrom kultury i innym dobrom intelektualnym.

${ }^{17}$ W. Daszkiewicz, op. cit., s. 99.
} 
znaczenie $^{18}$. W większości przypadków dobro o szczególnym znaczeniu dla kultury będzie miało także znaczną wartość w rozumieniu k.k. Zdaniem M. Dąbrowskiej-Kardas i P. Kardasa, nie należy wtedy w kwalifikacji powoływać art. $11 \S 2$ k.k. Powołani autorzy twierdzą: „Podstawą kwalifikacji powinien być przepis określający typ podstawowy czynu zabronionego wymieniony w art. $294 \S 1$ k.k. oraz przepisy art. $294 \S 1$ i art. $294 \S 2$ k.k. Tylko bowiem wskazanie w podstawie kwalifikacji wszystkich wymienionych przepisów pozwala na oddanie zawartości kryminalno-politycznej zachowania popełnionego przez sprawcę" ${ }^{, 19}$.

Nie wypełnia znamion tego typu kradzieży zabór w celu przywłaszczenia dobra o znaczeniu dla kultury, jeżeli nie jest to znaczenie szczególne. Najpierw należy stwierdzić, czy przedmiotem kradzieży było „dobro mające znaczenie dla kultury”, a następnie, czy owo znaczenie było szczególne. Musi mieć ono szczególną wartość dla kultury. Kradzież dobra kultury, które takiej szczególnej wartości nie posiada, należy kwalifikować W zależności od wartości materialnej (art. $126 \S 1,119 \S 1$ k.w. ${ }^{20}$ lub art. 278 § 1 k.k. albo art. $278 \S 1 \mathrm{w}$ zw. z art. 294 § 1 k.k.). Wskazuje się w doktrynie, że kwalifikowanie dobra kultury w oparciu o jego wartość majątkową jest niekorzystne, gdyż wartości artystyczne, naukowe i historyczne zabytków są w takiej sytuacji pomijane ${ }^{21}$. Ponadto precyzyjne określenie wartości majątkowej wielu rodzajów zabytków (np. zabytków archeologicznych) jest bardzo trudne ${ }^{22}$.

Szczególne znaczenie dobra dla kultury wiąże się $\mathrm{z}$ jego unikatowym i niepowtarzalnym charakterem lub znaczną wartością ${ }^{23}$. Wskazuje się w literaturze, że może ono wynikać np. z objęcia go ochroną prawną poprzez wpisanie do rejestru zabytków lub uznaniem za pomnik historii. ${ }^{24}$ Wyznacznikiem jego szczególnego charakteru może być również zaliczenie konkretnego obiektu do światowego dziedzictwa kulturalnego w ramach ratyfikowanej przez Polskę Konwencji UNESCO w sprawie ochrony światowego dziedzictwa

\footnotetext{
${ }^{18}$ M. Kulik, Przestępstwo i wykroczenie uszkodzenia rzeczy, Lublin 2005, s. 155-156

${ }^{19}$ M. Dąbrowska-Kardas, P. Kardas [w:] A. Zoll, op. cit., s. 485-486.

${ }^{20}$ Ustawa z 20.5.1971 - Kodeks wykroczeń. t.j. Dz.U. z 2015 r. poz. 1094 z późn. zm., dalej jako k.w.

${ }^{21}$ M. Trzciński, Przestępczość przeciwko zabytkom, Prokuratura i Prawo 2011, nr 6, s. 47-48.

${ }^{22}$ Ibidem, s. 47-48.

${ }^{23}$ M. Kulik [w:] M. Mozgawa (red.), Kodeks karny. Praktyczny komentarz, Kraków 2006, s. 577.

${ }^{24}$ Uznanie za pomnik historii następuje w drodze rozporządzenia Prezydenta RP wydanego na wniosek ministra właściwego do spraw kultury. Zgodnie z art. 15 ustawy z dnia z dnia 23 lipca 2003 r. o ochronie zabytków i opiece nad zabytkami, może to nastąpić w takim trybie w odniesieniu do zabytków nieruchomych wpisanych do rejestru lub parków kulturowych z określeniem ich granic. Przykłady pomników historii zob. A. Sośnicka, Przestępstwo i wykroczenie przywłaszczenia w polskim prawie karnym, Warszawa 2013, s. 125-127. Powołana autorka trafnie podkreśla, że kwalifikacja z art. $294 \S 2$ k.k. będzie możliwa jedynie w przypadku, gdy przedmiot wykonawczy będzie sam w sobie zabytkiem, a nie jedynie znajdował się w granicach zespołu zabytkowego.
} 
kulturalnego i naturalnego przyjętej w Paryżu 16.11.1972 r. ${ }^{25}$ Moim zdaniem, są to warunki wystarczające do uznania określonego przedmiotu za desygnat typu kwalifikowanego kradzieży, lecz nie są to warunki konieczne. Nie przesądza natomiast o spełnieniu omawianego znamienia kwalifikującego wpisanie przedmiotu czynności wykonawczej kradzieży do rejestru zabytków lub uznanie go za pomnik historii. Niemniej fakt ten powinien zostać uwzględniony przy subsumcji, gdyż wpływa na stopień znaczenia dla kultury, który może okazać się znaczny. Niewpisanie przedmiotu wykonawczego do rejestru zabytków lub nieuznanie go za pomnik historii, nie wyklucza uznania go za „dobro o szczególnym znaczeniu dla kultury”.

Zdaniem M. Trzcińskiego, wprowadzony przez ustawodawcę przepis, wbrew oczekiwaniom, nie wzmocnił prawnokarnej ochrony dóbr kultury, ponieważ znaczenie dla kultury musi mieć wartość szczególną ${ }^{26}$. W mojej ocenie, wymóg „szczególności” znaczenia dla kultury jest trafny. Przeważająca część zabytków przed ustanowieniem tego typu przestępstwa i tak była już chroniona, ponieważ przedstawiały one wartość majątkową, często nawet znaczną. Nie byłoby dobrym rozwiązaniem określenie znamienia omawianego typu kwalifikowanego jako „dobro o znaczeniu dla kultury” bez wyeksponowania jego szczególnej wartości. Bezprawie tak określonej kradzieży nie byłoby adekwatne do ustawowego zagrożenia przewidzianego za ten typ kwalifikowany. To właśnie owa szczególna wartość kultury przemawia za odrębną kryminalizacją. Pominięcie tego znamienia miałoby fatalne skutki. Znaczna część wytworów ludzkich ma jakieś znaczenie dla kultury np. powstające rzeźby i obrazy. Ich kradzież powinna być jednak kwalifikowana w oparciu o wartość majątkową, którą przedstawiają. Może to rodzić praktyczne trudności np. jak biegły ma ustalić wartość obrazu początkującego malarza, jeżeli obraz ten nie był jeszcze przedmiotem transakcji handlowej? Będzie to jedynie subiektywna ocena biegłego, od której zależy kwalifikacja.

Zdaniem S. Budzińskiego, jeżeli rzecz nie jest w obiegu ${ }^{27}$, cena rzeczy podobnego gatunku lecz nie „temi samemi przymiotami co skradziona, nie będzie rzeczywistą wartością rzeczy. Rozumie się, że sędziemu służyć winna możność miarkowania podanej ceny,

\footnotetext{
${ }^{25}$ Zob. M. Trzciński, op. cit., s. 44; W. Radecki, Ochrona..., s. 11 i n.; M. Kulik, op. cit., s. 159; J. Sobczak, Ochrona prawnokarna dóbr kultury, Środkowoeuropejskie Studia Polityczne 2009, nr 3, s. 12.

${ }^{26}$ M. Trzciński, op. cit., s. 44.

${ }^{27}$ Za taką należy uznać taki wspomniany wcześniej obraz. Nie chodzi o wyłączenie rzeczy z obiegu jako res extra commercium, lecz o rzeczy, które ze względu na swoją oryginalność nie mają swoich odpowiedników w obiegu i dlatego nie mają ceny rynkowej.
} 
np. gdyby pokrzywdzony oznaczał wysoką cenę predylekcyjną" ${ }^{28}$. Powołany autor nie wypowiadał się w odniesieniu do konkretnych przykładów, lecz wydaje się, że dzieło artystyczne będzie najlepszą egzemplifikacją omawianego problemu praktycznego. Pokazuje to ułomność kontrawencjonalizacji kradzieży, a także typów kwalifikowanych przez znaczną wartość (art. 294 w zw. z art. 278 k.k.). Wartość nie wszystkich rzeczy można ustalić obiektywnie, co nie byłoby konieczne, jeżeli nie wpływałoby na kwalifikację. Natomiast brak precyzyjnego ustalenia wartości skradzionej rzeczy jako okoliczności wymiaru kary, w sytuacji gdy jest to obiektywnie niemożliwe nie stanowi naruszenia prawa materialnego.

Zdaniem A. Gereckiej-Żołyńskiej, termin „dobro o szczególnym znaczeniu dla kultury" jest nieostry, lecz zapewnia ochronę prawną dobrom wpisanym do rejestru zabytków oraz tym, których zabytkowy charakter jest oczywisty. Podkreśla ona jednak, że omawiany przepis rodzi spory $w$ kwestii oceny wpisu do rejestru zabytków ${ }^{29}$. Autorka wskazuje, że podstawową przesłankę przyznania rzeczy „szczególnego znaczenia dla kultury" stanowi analiza jej statusu prawnego w zakresie uznania za zabytek w rozumieniu ustawy z dnia 23 lipca 2003 r. o ochronie zabytków i opiece nad zabytkami. Odwołanie się do niej powinno mieć charakter obligatoryjny, a nie pomocniczy ${ }^{30}$. Pojęcie „dobra kultury” ma szerszy zakres od terminu „zabytek”. Przedmiotem wykonawczym typu z art. 294 § 2 k.k. jest zarówno dobro o szczególnym znaczeniu dla kultury regionu, polskiej jak i światowej.

Trafnie podkreśla się w piśmiennictwie, że: „niejednolity system pojęć występujący na gruncie prawa ochrony dziedzictwa kultury, jest powodem wielu problemów związanych ze stosowaniem obowiązujących przepisów prawnych. Na gruncie prawnokarnej ochrony pojawiają się problemy z precyzyjnym określeniem przedmiotu ochrony. Organa procesowe korzystają w związku z tym dość często z opinii biegłych. Okazuje się bowiem, że wciąż zasadniczym problemem jest ustalenie różnicy pomiędzy dobrem o szczególnym znaczeniu dla kultury a zabytkiem. Dobro kultury jest pojęciem szerszym od pojęcia zabytku. Relacje pomiędzy tymi pojęciami są takie, że każdy zabytek stanowić będzie dobro kultury, natomiast nie każde dobro kultury wypełniać będzie znamiona ustawowe zabytku. Te same relacje dotyczyć będą dobra o szczególnym znaczeniu dla kultury i zabytku.

\footnotetext{
${ }^{28}$ S. Budziński, O przestępstwach $w$ szczególności. Wyktad porównawczy z uwzględnieniem prawo obowiazujacych na Królestwie Polskiem i Galicyi Austryackiej, Warszawa 1883, s. 163.

${ }^{29}$ A. Gerecka-Żołyńska, Rozważania wokót wspótczesnych problemów karnoprawnej i karnoprocesowej ochrony zabytków [w:] W. Szafrański (red.), Wokót problematyki prawnej zabytków i dziet sztuki, t. I, Poznań 2007, s. 132.

${ }^{30}$ Ibidem, s. 132.
} 
Szczególny charakter dobra kultury, co już zostało powiedziane, wynikać będzie z jego wyjątkowego charakteru i unikatowości”31.

M. Trzciński powołuje sprawę (sygn. Ds. 561/07/S), prowadzoną przez Prokuraturę Rejonową w Miechowie, w związku $\mathrm{z}$ podejrzeniem o popełnienie przestępstwa z art. $278 \S 1$ k.k. W zw. z art. $294 \S 2$ k.k. Przedmiotem przestępstwa miały być zabytki archeologiczne w postaci krzemiennych narzędzi oraz ułamków ceramiki naczyniowej. Biegłemu zadano m.in. pytanie, „czy ww. przedmioty należą do kategorii dóbr o szczególnym znaczeniu dla kultury. Biegły odpowiedział na to pytanie negatywnie, argumentując, iż «za kryterium dobra o szczególnym znaczeniu dla kultury winna być przyjęta unikatowość, informatywność, wartość artystyczna oraz symboliczna danego wytworu, czyli - im dany okaz rzadszy, im więcej zawiera w sobie informacji z zakresu szeroko rozumianej kultury materialnej, duchowej i społecznej, im bardziej można go określić jako dzieło sztuki oraz im większe ma znaczenie symboliczne dla grupy społecznej, religijnej czy narodu, tym jego znaczenie dla kultury wzrasta, staje się dobrem o szczególnym dla niej znaczeniu. Z drugiej strony, im bardziej dany okaz jest przedmiotem typowym, pospolitym, dostarczającym informacji głównie w kategoriach statystycznych, tym jego znaczenie dla szeroko rozumianej kultury jest mniejsze». W konsekwencji, prowadzone przez Prokuraturę postępowanie zostało umorzone, a oskarżonego uznano jedynie za winnego popełnienia wykroczenia $\mathrm{z}$ art. 119 § 1 k.w." ${ }^{32}$. Jak wskazuje powołany autor: „zapewne, gdyby zadano biegłemu pytanie, czy zatrzymane u oskarżonego przedmioty są zabytkami (archeologicznymi), ten potwierdziłby ten fakt jednoznacznie. $\mathrm{Tu}$ jednak pojawiłby się kolejny problem, bowiem przestępstwo kradzieży czy przywłaszczenia zabytku jako takie nie zostało wyodrębnione. W sytuacji zatem, kiedy organa procesowe stwierdzą, iż przedmiotem przestępstwa był zabytek, niebędący zarazem dobrem o szczególnym znaczeniu dla kultury, nie będą mogły sięgnąć po kwalifikowane typy przestępstw określone w art. $294 \S 2$ k.k. Przedmiot przestępstwa określony zostanie jako rzecz i zastosowanie znajdą zapewne podstawowe typy przestępstw"33.

\footnotetext{
${ }^{31}$ M. Trzciński, op. cit., s. 47-48.

${ }^{32}$ Wyrok Sądu Rejonowego w Miechowie z 3.4.2008 r. II W 265/07, cyt. za M. Trzciński, op. cit.,, s. 47-48.

${ }^{33}$ M. Trzciński, op. cit., s. 47-48.
} 


\section{Konkluzje}

W piśmiennictwie dość często nieprawidłowo określa się stronę podmiotową kradzieży. Zapomina się, że świadomość znamienia, w tym znamienia kwalifikującego, może występować jako tzw. świadomość pełna - świadomość konieczności jego realizacji lub tzw. świadomość niepełna - świadomość możliwości jego realizacji. Jest to określenie sfery intelektualnej i nie ma nic wspólnego z płaszczyzną wolicjonalną. Należy podkreślić, że kierunkowość działania nie wyklucza tzw. świadomości niepełnej, czyli możliwości realizacji określonego znamienia, w tym znamienia kierunkowego. Sprawca może działać w celu przywłaszczenia cudzej rzeczy, będąc w świadomości, że może ona mieć znaczną wartość lub stanowić dobro o szczególnym znaczeniu dla kultury. Spełnione są wtedy znamiona strony podmiotowej typu kwalifikowanego, choć, w mojej opinii, bezprawie kradzieży ${ }^{34}$ jest wyższe w przypadku świadomości pełnej.

M. Dąbrowska-Kardas i P. Kardas twierdzą: „W przypadku znamienia kwalifikującego określonego jako «dobro o szczególnym znaczeniu dla kultury» z uwagi na niedookreśloność tego pojęcia oraz możliwości różnorodnych ocen przedmiotu kulturowego, płaszczyzna świadomości odnosi się do obu kryteriów kwalifikujących; a więc zarówno do tego, że przedmiotem zamachu jest dobro o znaczeniu kulturowym (dobro o znaczeniu dla kultury), jak i tego, że znaczenie to jest znaczeniem szczególnym. Z uwagi na konstrukcję typu kwalifikowanego oraz elementy strony podmiotowej, za wątpliwą uznać należy tezę, iż w przypadku typu kwalifikowanego, gdzie znamię kwalifikujące charakteryzuje przedmiot zamachu jako dobro o szczególnym znaczeniu dla kultury, warunkiem odpowiedzialności sprawcy na podstawie art. 294 § 2 k.k., w związku z odpowiednim typem przestępstwa przeciwko mieniu wymienionym w art. $294 \S 1$ k.k., jest «ustalenie w konkretnym stanie faktycznym, że był on świadomy w ogóle tego, że będące przedmiotem jego czynu dobro (rzecz) jest dobrem kultury i godził się na to, że dobro to może mieć szczególne znaczenie dla kultury» (tak B. Michalski (w:) Kodeks karny. Część szczególna, t. II, Komentarz, s. 1074; W. Radecki, Ochrona dóbr kultury w nowym kodeksie karnym, s. 7 i n.). Przyjęcie takiej formuły interpretacyjnej w odniesieniu do wszystkich typów wymienionych w art. $294 \S 1$ k.k. prowadzi do istotnej modyfikacji znamienia strony podmiotowej, zwłaszcza w przypadku typów charakteryzujących się zawężoną postacią umyślności w formie zamiaru szczególnie

\footnotetext{
${ }^{34}$ Wydaje się, że wyższy jest także stopień winy sprawcy, który jest pewien, że rzecz ma znaczną wartość lub stanowi dobro o szczególnym znaczeniu dla kultury) niż sprawcy, który jest tylko świadomy takiej możliwości.
} 
zabarwionego (kierunkowego) oraz modyfikacją znamion strony przedmiotowej. W takim ujęciu, $w$ istocie dochodzi do modyfikacji znamienia kwalifikującego, które ze znamienia wymagającego ataku na dobro mające szczególne znaczenie dla kultury, staje się znamieniem określającym owo dobro jako «mogące mieć szczególne znaczenie dla kultury». Charakter dobra stanowiącego przedmiot zamachu, tj. zarówno jego przynależność do dóbr kultury, jak i jego szczególne znaczenie dla kultury, stanowią znamię czynu zabronionego, zatem sąd nie może zastosować kwalifikacji opartej na art. $294 \S 2$ k.k. do czynu sprawcy, jeżeli brak podstaw do przyjęcia, iż sprawca działał ze świadomością, że dobro miało szczególne znaczenie dla kultury"35. Powołani autorzy trafnie krytykują stanowisko B. Michalskiego i W. Radeckiego, choć niepotrzebnie posługują się terminem „godzi się”. Moim zdaniem, nie jest to błąd logiczny, gdyż na gruncie języka potocznego można godzić się na to, żeby rzecz miała konkretną wartość ${ }^{36}$. Należy jednak pamiętać, że termin ten ma w języku prawnym i dlatego powinien mieć też $\mathrm{w}$ prawniczym inną konotację wynikającą z art. $9 \S 1$ k.k. Przepis ten odnosi „godzenie się” do całości czynu. Dlatego, w mojej opinii, niewskazane jest używanie go w języku prawniczym w odniesieniu do konkretnego znamienia. Lepiej posługiwać się terminami określającymi sferę intelektualną tj. pełna lub niepełna świadomość określonego znamienia. Świadomość konieczności lub możliwości realizacji konkretnego znamienia statycznego nie determinuje określenia strony woluntatywnej w zakresie umyślności tj. nie przesądzają o tym, w jakim sprawca działa zamiarze (kierunkowym, bezpośrednim, czy ewentualnym). Aby to stwierdzić, należy analizować świadomość innych znamion oraz stronę wolicjonalną w odniesieniu do całości czynu. Oczywiście, jeżeli sprawca działa w świadomości konieczności realizacji wszystkich znamion statycznych i dynamicznych, to przesądza to o zamiarze bezpośrednim, lecz nie rozstrzyga jeszcze o zamiarze kierunkowym, który może zaistnieć lub nie. Natomiast jeżeli działa on w świadomości niepełnej wszystkich znamion przedmiotowych, to nie przesądza to nawet o formie winy. Wykluczone jest tylko niedbalstwo,

\footnotetext{
${ }^{35}$ M. Dąbrowska-Kardas, P. Kardas [w:] A. Zoll, op. cit., s. 489-490. A. Sośnicka (op. cit., s. 131-132) popiera natomiast stanowisko $B$. Michalskiego. Jej zdaniem, sprawca kradzieży dobra o szczególnym znaczeniu dla kultury powinien mieć świadomość, że jest to dobro kultury oraz godzić się na to, że przedmiot wykonawczy ma szczególne znaczenie dla kultury. Według powołanej autorski, wynika to z wybitnie ocennego charakteru terminu „szczególny”. Stanowisko to nie zasługuje na aprobatę. Sprawca tego przestępstwa może pozostawać w świadomości niepełnej, że przedmiot wykonawczy stanowi „dobro o szczególnym znaczeniu dla kultury”. Stawianie wymogu świadomości pełnej, że jest to dobro kultury, a świadomości niepełnej wyłącznie w odniesieniu do „szczególności” nie wydaje się uprawnione. Sferą intelektualną umyślności (art. 9 § 1 k.k.) jest bowiem także świadomość niepełna i przepis ten odnosi się także do znamion ocennych.

${ }^{36}$ Jednak termin „chęć” nawet na gruncie języka potocznego, nie powinien być odnoszony np. do znamienia „cudza”, ponieważ sprawca kradzieży nie chce, żeby rzecz była cudza. On właśnie chce, żeby była to jego własna rzecz i dlatego ją kradnie.
} 
lecz może to być lekkomyślność, zamiar kierunkowy, bezpośredni lub ewentualny. Konieczne są wtedy ustalenia dotyczące płaszczyzny woluntatywnej.

Przedmiot wykonawczy omawianego przestępstwa ma charakter niedookreślony, co może rodzić wątpliwości natury gwarancyjnej i konstytucyjnej. J. Pruszyński trafnie wskazuje, iż „określenie, że czyn wymierzony jest w dobro o szczególnym znaczeniu, jest praktycznie niemożliwe, gdyż znaczenia dla kultury nie da się w ogóle zdefiniować, a już kwalifikacja znaczenia szczególnego od zwykłego jest niewykonalna" 37 . Moim zdaniem, w dużej liczbie przypadków sąd będzie zmuszony zasięgnąć opinii biegłego (np. historyka sztuki, archeologa, konserwatora sztuki).

A. Sośnicka trafnie wskazuje, że brak definicji dobra o szczególnym znaczeniu dla kultury można uznać za błąd ustawodawcy. Także W. Radecki stawia pytanie, czy nie narusza to reguł gwarancyjnych i zasady określoności typu czynu zabronionego ${ }^{38}$. Natomiast zdaniem M. Kulika, art. 294 § 2 k.k. powinien zostać zlikwidowany, gdyż zniknęłyby wtedy trudności interpretacyjne związane $\mathrm{z}$ podwójnym przedmiotem ochrony i relacją do przepisów typizujących przestępstwa przeciwko zabytkom ${ }^{39}$.

Artykuł $294 \S 2$ k.k. jest wadliwy technicznie. Odnosi się on bowiem do wszystkich typów z art. $294 \S 1$ k.k., także tych, których przedmiotem nie może być dobro o szczególnym znaczeniu dla kultury (np. art. 287 § 1 k.k.). Dlatego słusznie podkreśla A. Sośnicka, że należy zrezygnować z uproszczenia redakcyjnego polegającego na automatycznym przeniesieniu przepisów z art. $294 \S 1$ k.k. i wymienić taksatywnie przepisy, do których odnosi się art. 294 § 2 k.k. ${ }^{40}$.

\footnotetext{
${ }^{37}$ J. Pruszyński, Dziedzictwo kultury Polski. Jego straty i ochrona prawna, t. 2, Kraków 2001, s. 604-605; krytycznie na ten temat zob. również J. Kaczmarek, M. Kierszka, op. cit., s. 116-119.

${ }^{38}$ W. Radecki, Ochrona ..., s. 8

${ }^{39}$ M. Kulik, op. cit., s. 132.

${ }^{40}$ A. Sośnicka, op. cit., s. 122.
} 


\section{Theft of the goods of particular cultural importance}

\section{Summary}

The criminal offense of the theft of goods of special cultural importance (article $294 \S 2$ of penal code) is a type of qualified theft. The object of this crime has been described with an imprecise term, which has no legal definition. Criminal Conversion of an object, in order to appropriate someone else's movable property constituting a good of a particular cultural importance, consists in intentional and unlawful exercising a right to ownership of the object in question, beyond the extent of a simple use of it, and disposing of it. The legislator does not introduce a partial decriminalization related to the criterion of amount in opposite to theft typified in the article $278 \S 1$ of penal code

\section{Tomasz Tyburcy}

Doktor nauk prawnych, absolwent Wydziału Prawa i Administracji Uniwersytetu Kardynała Stefana Wyszyńskiego oraz Studiów Doktoranckich na Wydziale Prawa i Administracji Uniwersytetu Warszawskiego (Instytut Prawa Karnego, Katedra Prawa Karnego). Autor publikacji z zakresu prawa karnego. Specjalizuje się w analizie struktury przestępstwa, przestępstwach przeciwko mieniu oraz bezpieczeństwu w komunikacji. 